\section{Transfusion Medicine and Hemotherapy}

\section{Clinical Information}

Transfus Med Hemother 2014;41:73-82

DOI: $10.1159 / 000357106$
Received: May 07, 2013

Accepted: May 09, 2013

Published online: Dezember 23, 2013

\title{
Usutu Virus
}

\author{
Arbeitskreis Blut, Untergruppe «Bewertung Blutassoziierter Krankheitserreger»
}

\section{Current Knowledge about the Pathogen}

Usutu virus (USUV) was first identified in 1959 by McIntosh as part of a study on the prevalence of viruses in arthropods in South Africa. It was isolated from Culex neavei (original classification Culex univittatus Theobald) by intracerebral inoculation of newborn mice [1]. In the following years, additional isolates were reported that originated from mosquito species, including those from Uganda and West African countries such as Senegal and the Central African Republic (RCA) [1-5]. The vast majority of the African isolates originated from a variety of different mosquito species including $C$. neavei, Culex perfuscus, Mansonia africana, Mansonia aurites und Aedes (Aedimorphus) minutus [6, 7 (review)]. It is assumed that USUV spreads in cycles between ornithophilic mosquitoes and birds - comparable with the epidemiology of West Nile virus (WNV) [8, 9]. In 1981, USUV was isolated for the first time from a patient with fever and skin rash in the RCA [5]. A second case of disease, a boy in Burkina Faso, was reported in 2004 by Nikolay et al. [7]. Increased attention was paid to the pathogen after USUV was isolated from dead blackbirds in Austria in 2001. Investigations into the prevalence and incidence of USUV infections have demonstrated that USUV has continued to spread in Europe. Especially the dying of blackbirds from USUV infection in Germany in 2011 [10] and a recent report of evidence of USUV infection in a blood donor in southern Germany have given rise to further public discussion [11].

\subsection{Characteristics of the Pathogen}

Because of its pronounced cross-reactivity in serological test methods, USUV is classified as a member of the antigen complex (serogroup) of the Japanese encephalitis virus (JEV) within the family of flaviviridae. Some representatives of these flaviviruses such as JEV, Saint Louis encephalitis virus (SLEV), Murray Valley encephalitis virus, as well as USUV are important pathogens for humans and/or animals $[9,12]$. Contrary to other representatives of flaviviridae such as WNV, yellow fever virus (YFV), and dengue virus (DENV), there are currently no comprehensive studies on the properties and replication of USUV. Based on the genome structure, however, it can be assumed that the virus behaves similarly to other flaviviruses such as WNV or DENV $[9,13]$. Like other flaviviruses, the USUV particle is enveloped, with the envelope being derived from membranes of the host cell. The virus envelope encapsulates the virus capsid that contains the positive-strand RNA genome with a length of around 11,000 nucleotides. Sequence analyses of USUV isolates have shown that, as in all other flaviviruses, the genome encodes a single polyprotein with a size of around 3,400 amino acids, that is processed by cellular and viral proteases into structural and non-structural proteins. The first 3 genes encode the 3 proteins necessary for the structure of the virus: the capsid protein $(\mathrm{C})$, the precursor membrane protein/membrane protein ( $\mathrm{prM} / \mathrm{M})$, and the envelope protein $(\mathrm{E})$. The right-hand part of the genome encodes 7 non-structural proteins with enzymatic activity and the regulatory proteins (fig. 1). The virus particle adheres to the host cell with its viral envelope protein E. The receptors on the cell responsible for adherence and uptake into the cell are unknown. Replication of the virus then occurs in the infected cell as described for other flaviviruses $[9,13]$.

\subsubsection{Stability}

Detailed studies on the stability of USUV are so far not available. It can be assumed, based on the data known on the stability of other flaviviruses such as DENV, YFV, FSMEV, and WNV, that USUV has properties comparable to these flaviviruses with regard to thermal stability and sensitivity against alcohols and detergents [14-18]. Detergent treatment and treatment at a low $\mathrm{pH}$ as applied in the manufacture of plasma products inactivate WNV and thus also seem to be suitable for USUV inactivation [19].

\section{KARGER \\ Fax +497614520714 \\ Information@Karger.com}

www.karger.com (c) 2014 S. Karger GmbH, Freiburg

1660-3796/14/0411-0073\$39.50/0

Accessible online at:

www.karger.com/tmh
Prof. Rainer Seitz

Paul-Ehrlich-Institu

Paul-Ehrlich-Straße 5-59, 63225 Langen, Germany

seira@pei.de 
Fig. 1. Genome structure of USUV: $\mathrm{C}=$ capsid protein/capsid protein; $\mathrm{prM}=$ precursor of the membrane proteins; $\mathrm{E}=$ surface glycoprotein (envelope protein); NS = non-structural protein; $\mathrm{UTR}=$ non-translated region; Cap = structure at 5' end; NS1 = inhibitor of signal transduction for innate immunity; NS2-NS2A = required for virus assembly and inhibitor of activation of the IFN- $\beta$ promoter; NS3 = multifunctional protein: serine protease (co-factor NS2B), 5'-RNA-triphosphatase (RTPase), nucleoside-triphosphatase (NTPase) and ATP-dependent RNA helicase; NS4-NS4A = modifies the endoplasmic reticulum, NS4B blocks IFN response; NS5 = RNA-dependent RNA polymerase, N-7- and 2'O-methyltransferase (MTase) for methylation of the 5'-RNA-cap structure.

\subsection{Infection and Infectious Disease}

Up to now, only few cases of USUV infections in humans have been reported. 2 cases of disease were reported from Africa (RCA and Burkina Faso) in the 1980s [7 (review)]. The virus could be isolated from the patient from the RCA, who developed fever and skin rash [3]. In Austria, 203 individuals who, due to the epidemiological situation, had an increased risk of USUV infection and had developed a skin rash of unknown cause, were tested for USUV-specific antibodies and by polymerase chain reaction (PCR) for USUV nucleic acid [20]. Patients with a documented Borrelia infection were excluded. Antibodies could be detected in 83 of these patients applying the hemagglutination inhibition assay. The plaque reduction neutralisation test (PRNT) confirmed neutralising antibodies against USUV in 52 of these patients, suggesting that around $25 \%$ of the patients who were selected on the basis of their epidemiological situation and clinical symptoms had been infected with USUV. Moreover, virus genome could be detected in 1 of the patients by PCR. The authors conclude that transient skin rash presents a clinical symptom for USUV infection, but that no severe signs of disease develop.

Severe courses of disease induced by USUV infections were described in 2009 in 2 immunocompromised patients in Italy, who both survived. One patient, over 60 years old, who had received chemotherapy after surgical removal of a B-cell lymphoma, developed fever and neurological symptoms after termination of treatment [21]. USUV genome could be demonstrated by PCR, and it could be shown by phylogenetic analysis that the pathogen was closely related to isolates from Austria and Hungary. Another case referred to a 40-year-old patient who had developed thrombotic-thrombocytopenic purpura a few days after a holiday in Egypt, and who was treated by extensive plasma exchange. 2 weeks later, she developed high fever and fulminant hepatitis with rapidly progressing neurological symptoms up to coma, which made a liver transplantation necessary. USUV genome could be detected by PCR in a plasma sample that was taken immediately before the transplantation [22]. Virus isolation on Vero cells and detection of nucleic acid by PCR provided proof of a USUV infection. In both cases, it has remained unclear whether the 2 patients had acquired the USUV infection naturally or by USUV-contaminated plasma donations, and to what extent USUV was responsible for the severe symptoms.
In Italy, patients with suspected meningoencephalitis were examined for USUV using a newly developed PCR method [23]. Virus genome could be detected in 3 of 44 patients in the cerebrospinal fluid (CSF), however, no virus genome could be detected in plasma and serum samples that were taken at the same time. Only 1 of the patients had antibodies against USUV in the serum and in the CSF.

Seroepidemiological tests of blood donors in Italy originating from a region endemic for USUV and WNV showed that around $1 \%$ of the donors had antibodies against USUV and $15 \%$ had antibodies against WNV [24]. These results indicated that both WNV and USUV are endemic in northern Italy, while no signs of disease are observed in infected people.

Infections in birds and mouse experiments have revealed that USUV displays different courses of infection depending on the species infected. Histological examination of the birds affected by the USUV epidemic in Austria (blackbird and great grey owl) showed hepatosplenomegaly, necroses in the nerve tissue, lesions in the myocardium, and necroses in the liver and spleen [25].

Experimental infections in mammals show that the course of USUV infections differs from that of WNV infections. Mice develop neurological symptoms after intraperitoneal infection with USUV, however, only if infected within 1 week after birth [26]. WNV, on the other hand, is able to infect older mice and induce fatal illness [27]. Fruit-eating African bats could not be experimentally infected with USUV [28].

Seroepidemiological studies of different bird species indicate that a multitude of birds can be infected with USUV and develop antibodies against the pathogen, without showing symptoms of the disease. USUV propagated in geese after experimental infection. The animals, however, did not show any clinical symptoms and only occasionally shed virus [29]. Similar results were also observed during experimental infection of chickens. Virus replication could be identified in some of the infected animals, but also in this case no clinical symptoms could be observed [30]. Chickens are often used for the surveillance of the spread of flaviviruses such as WNV or SLEV [31]. Since only part of the animals developed antibodies against USUV, the authors discussed to what extent these animals (sentinel chickens) were suitable for the monitoring of dissemination of USUV. 
Table 1. Detection of USUV in Europe

\begin{tabular}{|c|c|c|c|c|}
\hline Region (year) & Mammals & $\operatorname{Birds}^{\mathrm{a}, \mathrm{b}}$ & Mosquitoes & References \\
\hline Italy & $\begin{array}{l}\text { human }^{\mathrm{a}, \mathrm{b}, \mathrm{c}} \\
\text { horse }^{\mathrm{c}}\end{array}$ & $\begin{array}{l}\text { Common magpie (Pica pica) } \\
\text { Jay (Garrulus glandarius) } \\
\text { Common starling (Sturnus vulgaris) } \\
\text { Blackbird (Turdus merula) }\end{array}$ & $\begin{array}{l}\text { Aedes albopictus, } \\
\text { Culex pipiens }\end{array}$ & {$[37]$} \\
\hline $\begin{array}{l}\text { Austria } \\
\text { (2001) }\end{array}$ & human ${ }^{\mathrm{b}, \mathrm{c}}$ & $\begin{array}{l}\text { Blackbird (T. merula) } \\
\text { Great grey owl (Strix nebulosa) } \\
\text { Blue tit (Parus caeruleus) } \\
\text { Sparrow (Passer domesticus) } \\
\text { Great tit (Parus major) } \\
\text { Nut hatch (Sitta europaea) } \\
\text { Robin (Erithacus rubecula) } \\
\text { Song thrush (Turdus philomelos) }\end{array}$ & & {$[30,38]$} \\
\hline $\begin{array}{l}\text { Germany } \\
(2011)\end{array}$ & human $^{\mathrm{c}}$ & $\begin{array}{l}\text { Black bird (T. merula) } \\
\text { Common starling (S. vulgaris) } \\
\text { Domestic canary (Serinus canaria domestica) } \\
\text { Sparrow (P. domesticus) } \\
\text { Great grey owl (S. nebulosa) } \\
\text { Common kingfisher (Alcedo atthis) }\end{array}$ & $\begin{array}{l}\text { Culex pipiens } \\
\text { pipiens }\end{array}$ & {$[10,39]$} \\
\hline Switzerland & & $\begin{array}{l}\text { Sparrow (P. domesticus) } \\
\text { Black bird (T. merula) } \\
\text { Blue tit (P. caeruleus) } \\
\text { Green finch (Carduelis chloris) } \\
\text { Robin (Erithacus rubecula) } \\
\text { Boreal owl (Aegolius funereus) } \\
\text { Great grey owl/Lappland owl (S. nebulosa lapponica) } \\
\text { Northern hawk owl (Surnia ulula) } \\
\text { Eurasian pygmy owl (Glaucidium passerinum) }\end{array}$ & & {$[36]$} \\
\hline Spain & & & & {$[40,41]$} \\
\hline Hungary & & Blackbird (T. merula) & & {$[35]$} \\
\hline Serbia & horse $^{\mathrm{c}, \mathrm{d}}$ & & & [42] \\
\hline Czech Republic ${ }^{\mathrm{e}}$ & & antibody $^{\mathrm{d}}$ & & [43] \\
\hline Poland $^{e}$ & & antibody $^{\mathrm{d}}$ & & [44] \\
\hline \multicolumn{5}{|c|}{$\begin{array}{l}{ }^{\mathrm{a}} \text { Virus isolation. } \\
{ }^{\mathrm{b}} \text { Genome detection by means of PCR. } \\
{ }^{\mathrm{c} A n t i b o d y} \text { detection. } \\
{ }^{\mathrm{d}} \text { Also reactive with WNV in the PRNT. } \\
{ }^{\mathrm{e}} \text { It is unclear whether the antibodies were formed by infection of the birds in the respective region or whether the birds became infected in endemi }\end{array}$} \\
\hline
\end{tabular}

\subsection{Epidemiology}

Up to now, USUV has been isolated from different mosquito species, birds, and humans, or the occurrence of this pathogen has been determined in these species using nucleic acid amplification test (NAT) [7]. Most of the African USUV isolates were isolated from mosquitoes and only few from African birds (hornbill (Bycanistes sharpei), Little Greenbul (Andropadus virens), Kurrichane Thrush (Turdus libonya$n u s)$ ). These species are not migratory birds [6]. No reports are available on an increase in deaths among African birds. These birds are probably at least partly resistant against USUV infections and do not develop symptoms.

Unexpected was the detection of USUV in dead birds in Vienna, Austria, and its surrounding areas in 2001 [32]. Espe- cially affected were blackbirds (Turdus merula) and great grey owls (Strix nebulosa). In 2001 and 2002, USUV continued to spread in the region around Vienna. The programme for the surveillance of USUV developed by the University of Veterinary Medicine at Vienna (Veterinärmedizinische Universität Wien) permitted a continuous surveillance of USUV infections in the subsequent years. The number of dead birds in which USUV was detected was relatively low, however, it rose in the extremely hot summer of 2003 [25,33]. In the years that followed, the number of dead birds decreased compared with the peak of bird deaths of 2003, however, the pathogen continued to spread, particularly in the east of Austria [30]. Examinations of wild birds for antibodies against USUV revealed that in 2003 less than $10 \%$ of the birds investigated had neutralising antibodies; the percentage of antibody-positive 
birds, however, partly increased to above $50 \%$ in the following years [34].

After the description of USUV in Austria the number of publications on USUV infections in wild and captive birds in Europe increased in the following years [10, 30, 32, 35, 36] (table 1). Based on the monitoring programme in Austria, Hungary has been testing dead birds for USUV since 2003. In 2005, a blackbird tested positive for USUV in Budapest for the first time [35].

In northern Italy, antibodies against USUV were found in sera of sentinel chickens from 2005 and 2007 [45, 46]. Also in Italy, sera of horses in the Tuscany region and North-East Italy collected in 2008 and 2009 were positive for USUV-specific antibodies [47]. Direct proof of virus in Italy was provided in owls and blackbirds that had died between 2006 and 2008 after having shown signs of a virus infection with clinical symptoms [48]. USUV antibodies were also detected in a horse in Serbia [42]. In Germany, USUV was detected for the first time in 2010 in a mosquito pool of Culex pipiens that was collected in the area around the town of Weinheim (federal state of Baden-Württemberg) [39]. A year later, in 2011, USUV was identified in dead birds originating from the upper Rhine valley [10]. These findings show that the virus has spread in Europe since the beginning of the 21st century. Most of the death cases in Central Europe were observed in blackbirds(Turdus merula), however, lethal infections were also observed in other bird species [10, $30,35,36]$. Seroepidemiological studies of a great number of different bird species prove that some species can be infected but do not develop any clinical signs of disease.

Ornithophilic mosquitoes serve as vectors for the dissemination of the virus in the bird population, comparable to the WNV epidemiology [9]. The detection of antibodies against USUV in horses and humans proves that those mosquito species that can take their blood meal both on birds and on mammals can serve as so-called bridge vectors.

The detection of USUV sequences in and the isolation of USUV from mosquitoes in consecutive years provide evidence that USUV has become endemic in different regions of Europe [49]. This conclusion is supported by the detection of USUV in birds that developed the disease in consecutive years. Investigations of seroconversion in sentinel horses and chickens in Italy provided further evidence of the establishment of USUV in several regions of Europe [49].

Phylogenetic analysis of a limited number of USUV isolates from various regions and species using sequences of the entire genomes or of different genome regions show that distinct but closely related virus variants are circulating in Europe $[10,35,40,47,50]$. Sequences from USUV isolated in Austria, Hungary, Switzerland, Germany, and North-East Italy are closely related but can be differentiated from the USUV strain SAAR 1776 originally isolated in South Africa. In Spain, however, USUV was isolated from C. pipiens that is closely related to the South African SAAR 1776 strain, and similar isolates were also detected in Italian endemic areas.
This implies that USUV was introduced into Europe several times from the endemic areas in Africa, possibly by migratory birds. It remains unclear to what extent the genetic differences are responsible for the different pathogenic potential observed in birds.

The detection of USUV in $C$. pipiens points to the fact that not only can this mosquito species transmit USUV to birds but it can also act as bridge vector for the transmission to mammals including humans [51]. It is assumed that USUV is imported into Europe by migratory birds that become infected with USUV while living in or passing through endemic areas in Africa. Birds are regarded as reservoir and amplification host for USUV. It can be assumed that the enzootic cycle, comparable with the spreading of WNV between wild birds and ornithophilic mosquitoes, occurs in a variety of wetlands in the moderate climatic zones of Europe. Up to now, the viral load in viremic birds necessary to infect mosquitoes successfully has not yet been determined. For WNV it is known that more than $10^{5}$ infectious virus particles $/ \mathrm{ml}$ blood are required.

The differences in the course of USUV infections in birds in Europe compared with those in Africa could be due to the fact that USUV has been endemic in Africa for a long time, and birds living in these endemic areas have been continuously exposed to the pathogen and have developed partial resistance. Through natural selection, therefore, birds with a higher resistance against USUV infection had a better chance to survive. The introduction of USUV into Central Europe and the European part of the Mediterranean area with subsequent dissemination in the bird population shows parallels to the epidemiology of WNV in America.

Comprehensive studies on the course of infection with different USUV variants circulating in infected birds or mammals - including humans - in Europe are not yet available. It is noteworthy that USUV-specific antibodies were already identified in previous years in different birds that generally belong to the migratory birds. It is unclear to what extent natural selection has already taken place in these species that migrate to Africa for the winter, so that despite a possible infection with viremia, the animals do not develop the disease and survive the infection. Such bird species would thus be in a position to spread the virus [12, 52-54].

\subsubsection{Detection of USUV in Mosquitoes}

USUV has been detected in a variety of mosquito species in Europe and Africa. The German Mosquito Control Association (Kommunale Aktionsgemeinschaft zur Bekämpfung der Schnakenplage; KAPS) at Philippsburg has been carrying out extensive studies on the prevalence of mosquito species in the Upper Rhine valley since 1991. These studies show that mosquito species are common in this region that can potentially transmit USUV among birds but also from birds to humans or other mammals such as horses [55]. Detection and isolation of USUV from $C$. pipiens provided proof that USUV is already endemic in the Upper Rhine valley [39]. In Ger- 
many it is not mandatory to report the detection of USUV or USUV-associated diseases. If USUV-associated diseases in humans would occur frequently, reporting would be notifiable pursuant to Section 6 (1) number 5a of the German Protection against Infections Act (Infektionsschutzgesetz; IfSG).

\subsection{Detection Methods and Significance}

A USUV infection can be diagnosed by the proof of specific antibodies and/or by virus isolation in cell culture or by identifying the viral genome using NAT. So far, no validated commercial assays are available either for the determination of specific antibodies or for the viral genome.

\subsubsection{Serological Detection}

Since no specific antibody detection tests are available for USUV, WNV antibody detection tests such as ELISA tests with WNV antigens or WNV-infected cells are currently used to screen for USUV antibodies. Some investigators use inhouse tests based on USUV antigens. As confirmatory test, the PRNT is performed. The serological diagnosis of an acute USUV infection is carried out by determination of USUVspecific IgM antibodies in serum or CSF [24].

Evidence of a fresh USUV infection is provided by seroconversion of virus-specific IgM to IgG or a 4-fold increase in antibodies in 2 samples taken at an interval of 10 days. To rule out the existence of cross-reacting antibodies or false-positive results, reactivity must be confirmed by USUV-specific tests, particularly if antibody detection was based on enzyme immunoassays, immunofluorescence, or hemagglutination inhibition tests. The gold standard for the confirmation of USUVspecific antibodies, and thus the exclusion of antibodies against other flaviviruses, is the PRNT. It should be taken into account that the determination of $\operatorname{IgM}$ antibodies might cause a comparatively high rate of false-positive results, as was observed in the USA for the determination of $\operatorname{IgM}$ antibodies against WNV [56].

According to the current serological test results, the impact of cross-reactive antibodies against other flaviviruses on the detection of USUV infections has to be clarified. Such crossreactive antibodies might be induced by vaccination against yellow fever, Japanese encephalitis, or tick-borne encephalitis, or by an infection with flaviviruses such as DENV, FSMEV, or JEV after travelling to the respective endemic areas. Cross-reactivity with antibodies against WNV was observed that can be ruled out by determining pathogen-specific antibodies in virus neutralisation tests like the PRNT [57-59].

Originally, USUV was isolated by intracerebral inoculation of mosquito homogenates in newborn mice [1]. Differences in susceptibility were observed for the infection of cell cultures derived from different species. Such investigations were performed using the Austrian isolate from a blackbird that was originally isolated on Vero cells (kidney cells from the Afri- can green monkey). Some cells such as PK15 (kidney cells of the pig) and embryonic goose fibroblasts (EGF) developed a pronounced cytopathic effect, while other cells, e.g. Hela cells, could be infected but did not show any cytopathogenic modifications [60]. No virus replication was found in chicken embryofibroblasts or embryonated chicken eggs [47, 60]. The extent to which a newly established cell line from the bank vole (Myodes glareolus) seems to be particularly suitable for the isolation of USUV remains to be further investigated [61].

In Hungary, USUV was isolated from dead birds on embryonic goose fibroblasts and in Italy and Germany on Vero cells [10, 35, 47]. Jöst et al. [39] reported successful isolation of USUV from mosquitoes in C6/36 cells, while attempts to isolate USUV from a PCR-positive mosquito pool in Spain on Vero cells were unsuccessful [41]. The extent to which the differences observed in the growth behaviour on different cells or species provide evidence of differences in the pathogenic potential of USUV should be further studied.

\subsubsection{Detection of the Virus Genome}

NAT procedures such as reverse transcription (RT)-PCR/ real-time PCR or transcription-mediated amplification (TMA) have proved to be sensitive for the detection of viral genomes. Different methods for the detection of USUV sequences have been described in the literature; sequences from the NS5 genome are mainly used for the establishment of USUV-specific genome detection tests $[23,26]$. Also of interest is the development of pan-flavivirus NATs that are designed to recognise different flaviviruses in clinical materials [10, 62-64]. Viral sequences detected in the pan-flavivirus PCR can be further differentiated by sequencing the PCR product or by using virus-specific NATs. Validation of NAT with regard to sensitivity and specificity has not yet been performed. A method suitable for the further characterisation and differentiation of NAT-positive samples is genome sequencing with subsequent phylogenetic analysis, which permits a molecular epidemiology-based classification of the isolates or of circulating viruses detected by PCR. Using this approach, a positive result in the WNV-TMA could be identified as USUV infection. Furthermore, using a flavivirus PCR, a JEV sequence was surprisingly detected in a mosquito pool in Italy [65]. Follow-up tests of material from dead birds collected in Italy between 1997 and 2000 also contained JEV sequences [66]. These results point to the fact that JEV or a virus closely related to $\mathrm{JEV}$ is present in this region and was possibly imported by migratory birds.

\section{Blood and Plasma Donors}

\subsection{Prevalence and Incidence in Donor Populations}

Up to now, only few USUV infections in humans have been reported. Before the occurrence of USUV in Europe 
(Austria) in 2001, only 2 infections in humans had been known in Africa [7 (review)]. Screening of blood donors in the Ferrara region (North-East Italy), in which WNV infections had been observed, showed that around $16 \%$ of the donors (53/359) had antibodies against WNV and 4 of the donors had antibodies against USUV [24]. Interviewing of the donors concerning disease symptoms within the 4-month period before the antibody-positive donation showed that none of the donors had developed fever during this period. It has however been discussed that USUV - similarly to WNV leads to the development of viremia before the occurrence of $\mathrm{IgG}$; however, no information is available as to the extent and duration of viremia. The detection of USUV antibodies in a blood donor in Germany points to the fact that USUV can be transmitted to humans in Germany, too, without causing any symptoms [11].

\subsection{Definition of Exclusion Criteria}

The findings presently available on the prevalence and incidence of USUV infections do not permit a definition of exclusion criteria. The extent to which general exclusion criteria such as fever would reduce the risk of a USUV transmission by blood or blood products is unclear, since no signs of febrile illness exist in most persons who tested serologically positive.

\subsection{Donor Testing and Significance}

Screening of blood donors with antibody tests is not performed and is not indicated either, since antibody-positive donations as a rule only point to a USUV infection that took place in the past. Blood and plasma donations can be tested for viral RNA using PCR or other NAT methods [23]. However, it has to be considered that at present insufficient information on the duration of USUV viremia in humans is available. Furthermore, it has not been proven that USUV can be transmitted by blood products. Regarding the screening of blood donors it remains to be further investigated to what extent pan-flavivirus NAT systems can be applied to detect genome sequences of different flaviviruses (such as WNV and USUV) with comparable sensitivity and specificity [64].

\subsection{Donor Interviews}

Staying in an area in which USUV has been detected in mosquitoes, birds, or other species theoretically presents a risk of acquiring a USUV infection. However, considering the fact that USUV has spread in the German bird population, obviously large areas will have to be considered as potential endemic regions in future, and special donor interviews would therefore not appear to be meaningful.

\subsection{Donor Information and Counselling}

Specific counselling on USUV infections and USUV prophylaxis can take place in infectiology centres or institutes for tropical diseases.

\section{Recipients}

\subsection{Prevalence and Incidence of Blood-Associated}

Infections and Infectious Diseases in Recipient Populations

Only few USUV infections in humans have been reported so far. Up to the time point when USUV first occurred in Europe (Austria) in 2001, only 2 cases of infection in humans in Africa had been reported [7 (review)]. The detection of USUV antibodies in blood donors in Italy and in 1 blood donor in Germany points to the fact that USUV infections occur in the blood donor population, that however as a rule take a non-symptomatic course in infected individuals. Whether or not, and to what extent and length of time, such blood donors are viremic, has so far not been sufficiently studied and is therefore unknown.

\subsection{Immune Status (Resistance, Existing Immunity, Immune Response, Age, Exogenous Factors)}

Seroepidemiological investigations give rise to the conclusion that USUV strains presently circulating in Europe usually lead to non-symptomatic infections. Reports on the association between USUV infections and the development of skin rash, however, give rise to the assumption that mild symptoms can occur after an infection. It is noteworthy that USUV might lead to serious neurological disorders in immunocompromised individuals, comparable with courses of infection with WNV.

\subsection{Severity and Course of the Disease}

The 2 immunocompromised patients in Italy, whose disease had taken a neurological course (such as meningoencephalitis), recovered [21, 22]. In view of the few cases that have so far become known, it cannot be predicted to what extent parallels can be drawn between the course of USUV infections and that of WNV infections.

\subsection{Therapy and Prophylaxis}

Up to now, only few symptomatic infections with USUV have been observed in humans so that there is as yet no experience with regard to treatment of the disease. As in other flavivirus infections, only symptom-related treatment is available. 


\subsubsection{Antiviral Substances}

No antiviral USUV-specific treatment is currently available. Elucidating the structure of viral enzymes such as helicase will provide approaches to developing virus-specific therapeutics [67]. For various other flaviviruses, antiviral substances are being studied extensively in various different working parties [68-70 (reviews)]. Whether these substances are also suitable for use in USUV infections remains to be seen.

\subsubsection{Prophylaxis}

Up to now, no information on the development of vaccines for prophylaxis in humans or animals including birds is available. The only efficient prophylaxis is avoiding mosquito bites in regions where USUV is endemic or in which transmissions of USUV have been reported.

\subsection{Transmissibility}

As a rule, USUV is transmitted by infected mosquitoes; other transmission pathways have so far not been reliably elucidated. In Italy, a national WNV surveillance plan has been introduced that lays down that all blood and plasma donations in regions where WNV is endemic must be tested during the period from 15 June to 15 November by PCR. This also concerns the testing of tissue and organ donations. Furthermore, all cases with symptoms compatible with a WNV infection are clarified using serological and virological methods. As far as the 2 cases of USUV infection in immunocompromised patients are concerned, it has not yet been clearly established whether the patients became infected naturally or by blood transfusion [21, 22].

\subsection{Frequency of Administration, Type, and Amount of Blood Products}

Based on the assumption that infections with USUV in humans take a course comparable with that of WNV infections, transmission of USUV can occur by non-inactivated blood products (erythrocyte concentrates, fresh frozen plasma, platelet concentrates) [71, 72], but not by virus-inactivated blood components or plasma products.

\section{Blood Products}

\subsection{Infectious Load of the Starting Material and Test Methods}

No validated commercial NAT tests are available at present for the detection of USUV RNA. Antibody tests of blood donors in Italy and Germany provide evidence that USUV infections took place in potentially endemic areas.
Up to now, no USUV viremia could be detected using PCR in a limited number of donors, above all in endemic areas in Italy.

\subsection{Methods for Removal and Inactivation of the Infectious Agent}

The capacity of virus inactivation in the manufacture of plasma derivatives was determined using relevant model viruses. Based on the studies available up to now, all flaviviruses tested (bovine virus diarrhoea virus, FSMEV, WNV) are sensitive to the inactivation methods used [14, 19, 73]. Pooled plasma treated with the solvent/detergent methods is safe, since flaviviruses and other enveloped viruses are effectively inactivated [74 (review)]. Methylene blue in combination with photoinactivation inactivates flaviviruses in plasma [75]. Amotosalen hydrochloride (Psoralen, S-59) and ultraviolet (UV) light (intercept method) inactivate a number of pathogens including flaviviruses in plasma and thrombocyte preparations [76-78]. Riboflavin in combination with UV light treatment led to an effective reduction of WNV as well as a number of other pathogens in plasma and in thrombocyte concentrates [79]. The safety of blood products manufactured using various inactivation methods and their therapeutic use were assessed in review articles by Solheim [80] and Rock [81].

\subsection{Feasibility and Validation of Procedures for Removal/Inactivation of the Infectious Agent}

USUV replicates in suitable cell cultures to high titres. The titre of infectious particles can be determined using the plaque test (determination of the plaque-forming units) or by means of end point titration (determination of the tissue culture infectious dose $50 \%$ ). Blood and plasma components can be contaminated with USUV experimentally. The elimination/ inactivation of USUV in the various production steps can then be performed by determination of infectious viruses. Based on the findings available, all known flaviviruses behave in a comparable manner toward the various different inactivation/elimination methods. A USUV-specific validation of different production steps is therefore not indicated.

\section{Assessment}

The dissemination of USUV in the various different bird populations in Europe including Germany and infections in humans detected by serological and virological tests require increased attention. Whether or not an infection with this virus leads to severe disease in immunocompetent individuals, is so far unclear and requires further observation and scien- 
tific evaluation. The few cases of disease in Italy have all been in connection with immunosuppression. So far, no disease due to USUV infection has been observed in Germany.

To assess the risk of the spreading of USUV in Germany, it is required to establish a multidisciplinary collaboration between biologists (ornithologists), entomologists, veterinarians, physicians, and climatologists in joint long-term projects, as has already been suggested for WNV by this group [9]. In these projects, evidence can be found of the risk of importation to Germany and/or the dissemination of USUV within and the introduction of WNV and other arboviruses into Germany.

Blood components and plasma derivatives manufactured with validated virus inactivation methods are safe. What cannot be ruled out, however, is the risk of a USUV transmission by non-inactivated blood components, even if no transmission by blood has so far been identified in Germany. Individuals with encephalitis or meningitis of unclear etiology should be tested for the presence of a USUV infection. Likewise, fever and disorders of the central nervous system following transfusion of non-inactivated blood components could point to a transfusion-associated USUV infection, especially in immunocompromised patients. A differential diagnosis should be performed to rule out other forms of encephalitis due to arboviruses, herpes encephalitis, Guillain-Barré syndrome, and bacterial meningoencephalitis.

The testing of blood and plasma donations for viral genome using NAT methods could in principle reduce the risk of a transmission. A statement - comparable to the procedure for WNV - about whether blood and plasma donations should be tested for the presence of USUV genome during the seasons in which a transmission of the pathogen by mosquitoes is likely cannot be made based on the current state of knowledge. The introduction of USUV testing of blood donations, however, does not appear to be currently indicated due to the epidemiological data available and the few cases of infection in humans so far observed which have had mild or non-symptomatic courses.

Various different mosquito species play an essential role as vector in the spreading of USUV. The replication of USUV in the mosquito vector, however, largely depends on regional climatic conditions. It is therefore indicated not only to collect further findings on the pathogenesis of USUV, but also to observe further the geographic and temporal spreading of USUV in Germany. A reassessment of the pathogen in the context of blood safety might become necessary if a new state of knowledge is reached on the epidemiology and the pathopotential of USUV infections.

This paper was completed on 14 February 2013, and approved by the German Advisory Committee Blood (Arbeitskreis Blut) on 5 March 2013. It was compiled by the members of the subgroup 'Assessment of Pathogens Transmissible by Blood' of the German Advisory Committee 'Blood' (Arbeitskreis Blut):
Prof Dr Georg Pauli
Dr Ursula Bauerfeind
Dr Johannes Blümel
Prof Dr Reinhard Burger
Prof Dr Christian Drosten
Dr Albrecht Gröner
Prof Dr Lutz Gürtler
Dr Margarethe Heiden
Prof Dr Martin Hildebrandt
Prof Dr Dr Bernd Jansen
Dr Ruth Offergeld
Prof Dr Rainer Seitz
Dr Uwe Schlenkrich
Dr Volkmar Schottstedt
Dr Johanna Strobel
Dr Hannelore Willkommen

\section{References}

1 Williams MC, Simpson DI, Haddow AJ, Knight EM: The isolation of West Nile Virus from man and of Usutu virus from the bird-biting mosquito Mansonia aurites (Theobald) in the Entebbe area of Uganda. Ann Trop Med Parasitol 1964;58:367-374.

2 CRORA Senegal: www.pasteur.fr/recherche/ banques/CRORA/souches/sras1.html (retrieved 14 Sept 2012).

3 CRORA RCA: www.pasteur.fr/recherche/banques/ CRORA/souches/sqas1.html (retrieved 14 Sept 2012).

4 Woodall JP: The viruses isolated from arthropods at the East African Virus Research Institute in the 26 years ending December 1963. Proc E Afr Acad 1964:II:141-146.

5 CRORA Flavivirus USUTU: www.pasteur.fr/ recherche/banques/CRORA/virus/v010050.html (retrieved 14 Sept 2012).

6 CDC Arbocat USUV: www.cdc.gov/arbocat/catalog-listing.asp? VirusID $=503 \& S I=1 \quad$ (retrieved 19 Sept 2012).

7 Nikolay B, Diallo M, Boye CS, Sall AA: Usutu virus in Africa. Vector Borne Zoonotic Dis 2011; 11:1417-1423.
8 Kilpatrick AM, Kramer LD, Jones MJ, Marra PP, Daszak P: West Nile virus epidemics in North America are driven by shifts in mosquito feeding behavior. PLoS Biol 2006;4:e82.

9 Pauli G, Bauerfeind U, Blümel J, et al: West-NilVirus. Bundesgesundheitsbl Gesundheitsforsch Gesundheitsschutz 2012;55:1024-1043.

10 Becker N, Jöst H, Ziegler U, et al: Epizootic emergence of Usutu virus in wild and captive birds in Germany. PLoS One 2012; 7:e32604.

11 Allering L, Jöst H, Emmerich P, et al: Detection of Usutu virus infection in a healthy blood donor from south-west Germany, 2012. Euro Surveill 2012;17:pii = 20341; available online: $w$ ww.eurosurveillance.org/ViewArticle.aspx? ArticleId $=20341$.

12 Weissenböck H, Hubálek Z, Bakonyi T, Nowotny $\mathrm{N}$ : Zoonotic mosquito-borne flaviviruses: worldwide presence of agents with proven pathogenicity and potential candidates of future emerging diseases. Vet Microbiol 2010;140:271-280.

13 Gürtler L, Bauerfeind U, Blümel J, et al: Dengue Fieber Virus (DENV). Bundesgesundheitsbl Gesundheitsforsch Gesundheitsschutz 2011;54:892-904.
14 Kreil TR, Berting A, Kistner O, Kindermann J: West Nile virus and the safety of plasma derivatives: verification of high safety margins, and the validity of predictions based on model virus data. Transfusion 2003;43:1023-1028.

15 Song H, Li J, Shi S, Yan L, Zhuang H, Li K: Thermal stability and inactivation of hepatitis $\mathrm{C}$ virus grown in cell culture. Virol J 2010;7:40.

16 Fang Y, Brault AC, Reisen WK: Comparative thermostability of West Nile, St. Louis encephalitis, and western equine encephalomyelitis viruses during heat inactivation for serologic diagnostics. Am J Trop Med Hyg 2009;80:862-863.

17 Xie YW, Chan PK, Szeto CK, et al: Clearance of dengue virus in the plasma-derived therapeutic proteins. Transfusion 2008;48:1342-1347.

18 Remington KM, Trejo SR, Buczynski G, et al: Inactivation of West Nile virus, vaccinia virus and viral surrogates for relevant and emergent viral pathogens in plasma-derived products. Vox Sang 2004;87:10-18. 
19 Kreil TR: West Nile virus: recent experience with the model virus approach. Dev Biol (Basel) 2004; 118:101-105.

20 Weissenböck H, Chvala S, Bakonyi T, Nowotny N: Emergence of Usutu virus in central Europe: diagnosis, surveillance and epizoology; in Takken W, Knols B (eds): Emerging Pests and Vector-Borne Disease in Europe. Wageningen, Wageningen Academic Publishers, 2007, pp 153-168.

21 Pecorari M, Longo G, Gennari W, et al: First human case of Usutu virus neuroinvasive infection, Italy, August-September 2009. Euro Surveill 2009; 14:pii $=19446$.

22 Cavrini F, Gaibani P, Longo G, et al: Usutu virus infection in a patient who underwent orthotropic liver transplantation, Italy, August-September 2009. Euro Surveill 2009;14:pii $=19448$.

23 Cavrini F, Della Pepa ME, Gaibani P, et al: A rapid and specific real-time RT-PCR assay to identify Usutu virus in human plasma, serum, and cerebrospinal fluid. J Clin Virol 2011;50:221-223.

24 Gaibani P, Pierro A, Alicino R, et al: Detection of Usutu-virus-specific IgG in blood donors from northern Italy. Vector Borne Zoonotic Dis 2012;12: 431-433.

25 Chvala S, Kolodziejek J, Nowotny N, Weissenböck $\mathrm{H}$ : Pathology and viral distribution in fatal Usutu virus infections of birds from the 2001 and 2002 outbreaks in Austria. J Comp Pathol 2012;131:176-185.

26 Weissenböck H, Bakonyi T, Chvala S, Nowotny N Experimental Usutu virus infection of suckling mice causes neuronal and glial cell apoptosis and demyelination. Acta Neuropathol 2004;108:453-460.

27 Morrey JD, Olsen AL, Siddharthan V, et al: Increased blood-brain barrier permeability is not a primary determinant for lethality of West Nile virus infection in rodents. J Gen Virol 2008;89:467-473.

28 Simpson DIH, O'Sullivan JP: Studies on arboviruses and bats (Chiroptera) in East Africa. I. Experimental infection of bats and virus transmission attempts in Aedes (Stegomyia) aegypti. Ann Trop Med Parasit 1968;62:422-431.

29 Chvala S, Bakonyi T, Hackl R, Hess M, Nowotny $\mathrm{N}$, Weissenböck H: Limited pathogenicity of Usutu virus for the domestic goose (Anser anser f. domestica) following experimental inoculation. J Vet Med B Infect Dis Vet Public Health 2006;53:171-175.

30 Chvala S, Bakonyi T, Bukovsky C, et al: Monitoring of Usutu virus activity and spread by using dead bird surveillance in Austria, 2003-2005. Vet Microbiol 2007;122:237-245.

31 Chevalier V, Lecollinet S, Durand B: West Nile virus in Europe: a comparison of surveillance system designs in a changing epidemiological context. Vector Borne Zoonotic Dis 2011;11:1085-1091.

\32 Weissenböck H, Kolodziejek J, Url A, Lussy H, Rebel-Bauder B, Nowotny N: Emergence of Usutu virus, an African mosquito-borne flavivirus of the Japanese encephalitis virus group, central Europe. Emerg Infect Dis 2002;8:652-656.

33 Brugger K, Rubel F: Simulation of climate-change scenarios to explain Usutu-virus dynamics in Austria. Prev Vet Med 2009;88:24-31.

34 Meister T, Lussy H, Bakonyi T, et al: Serological evidence of continuing high Usutu virus (Flaviviridae) activity and establishment of herd immunity in wild birds in Austria. Vet Microbiol 2007;127:237-248.

35 Bakonyi T, Erdélyi K, Ursu K, et al: Emergence of Usutu virus in Hungary. J Clin Microbiol 2007;45: 3870-3874.
36 Steinmetz HW, Bakonyi T, Weissenböck H, et al: Emergence and establishment of Usutu virus infection in wild and captive avian species in and around Zurich, Switzerland - genomic and pathologic comparison to other central European outbreaks. Vet Microbiol 2011;148:207-212.

37 Tamba M, Bonilauri P, Bellini R, et al: Detection of Usutu virus within a West Nile virus surveillance program in Northern Italy. Vector Borne Zoonotic Dis 2011;11:551-557.

38 Weissenböck H, Kolodziejek J, Fragner K, Kuhn R, Pfeffer M, Nowotny N: Usutu virus activity in Austria, 2001-2002. Microbes Infect 2003;5:1132-1136.

39 Jöst H, Bialonski A, Maus D, et al: Isolation of Usutu virus in Germany. Am J Trop Med Hyg 2011;85:551-553.

40 Busquets N, Alba A, Allepuz A, Aranda C, Ignacio Nuñez J: Usutu virus sequences in Culex pipiens (Diptera: Culicidae), Spain. Emerg Infect Dis 2008;14:861-863.

41 Vázquez A, Ruiz S, Herrero L, et al: West Nile and Usutu viruses in mosquitoes in Spain, 2008-2009. Am J Trop Med Hyg 2011;85:178-181.

42 Lupulovic D, Martín-Acebes MA, Lazic S, et al: First serological evidence of West Nile virus activity in horses in Serbia. Vector Borne Zoonotic Dis 2011;11:1303-1305.

43 Hubálek Z, Halouzka J, Juricová Z, et al: Serologic survey of birds for West Nile flavivirus in southern Moravia (Czech Republic). Vector Borne Zoonotic Dis 2008a;8:659-666.

44 Hubálek Z, Wegner E, Halouzka J, et al: Serologic survey of potential vertebrate hosts for West Nile virus in Poland. Viral Immunol 2008b;21:247-253.

45 Rizzoli A, Rosà R, Rosso F, Buckley A, Gould E: West Nile virus circulation detected in northern Italy in sentinel chickens. Vector Borne Zoonotic Dis 2007;7:411-417.

46 Lelli R, Savini G, Teodori L, et al: Serological evidence of Usutu virus occurrence in north-eastern Italy. Zoonoses Public Health 2008;55:361-367.

47 Savini G, Monaco F, Terregino C, et al: Usutu virus in Italy: an emergence or a silent infection? Vet Microbiol 2011;15:264-274.

48 Manarolla G, Bakonyi T, Gallazzi D, et al: Usutu virus in wild birds in northern Italy. Vet Microbiol 2010;141:159-163.

49 Calzolari M, Gaibani P, Bellini R, et al: Mosquito, bird and human surveillance of West Nile and Usutu viruses in Emilia-Romagna region (Italy) in 2010. PLoS One 2012;7:e38058.

50 Bakonyi T, Gould EA, Kolodziejek J, Weissenböck H, Nowotny N: Complete genome analysis and molecular characterization of Usutu virus that emerged in Austria in 2001: comparison with the South African strain SAAR-1776 and other flaviviruses. Virology 2004;328:301-310.

51 Hayes EB, Komar N, Nasci RS, Montgomery SP, O'Leary DR, Campbell GL: Epidemiology and transmission dynamics of West Nile virus disease. Emerg Infect Dis 2005;20:1167-1173.

52 Linke S, Niedrig M, Kaiser A, et al: Serologic evidence of West Nile virus infections in wild birds captured in Germany. Am J Trop Med Hyg 2007; 77:358-364.

53 Bakonyi T, Ivanics E, Erdélyi K, et al: Lineage 1 and 2 strains of encephalitic West Nile virus, central Europe. Emerg Infect Dis 2006;12:618-623.

54 Calistri P, Giovannini A, Hubálek Z, et al: Epidemiology of West Nile in Europe and in the Mediterranean basin. Open Virol J 2010;4:29-37.

55 Becker N, Huber K, Pluskota B, Kaiser A: Ochlerotatus japonicus japonicus - a newly established neozoan in Germany and a revised list of the German mosquito fauna. Eur Mosq Bull 2011;29:88-102.
66 Janusz KB, Lehman JA, Panella AJ, Fischer M, Staples E: Laboratory testing practices for West Nile virus in the United States. Vector Borne Zoonotic Dis 2011;11:597-599.

57 Linke S, Muehlen M, Niedrig M, et al: Assessing the exposure of German and Austrian bird ringers to West Nile virus (Flavivirus) and evaluating their potential risk of infection. J Ornithol 2008;149:271-275.

58 Pfleiderer C, Blümel J, Schmidt M, et al: West Nile virus and blood product safety in Germany. J Med Virol 2008;80:557-563.

59 Papa A, Xanthopoulou K, Gewehr S, Mourelatos $\mathrm{S}$ : Detection of West Nile virus lineage 2 in mosquitoes during a human outbreak in Greece. Clin Microbiol Infect 2011;17:1176-1180.

60 Bakonyi T, Lussy H, Weissenböck H, Hornyák A Nowotny N: In vitro host-cell susceptibility to Usutu virus. Emerg Infect Dis 2005;11:298-301.

61 Essbauer SS, Krautkrämer E, Herzog S, Pfeffer M: A new permanent cell line derived from the bank vole (Myodes glareolus) as cell culture model for zoonotic viruses. Virol J 2011;8:339.

62 Scaramozzino N, Crance JM, Jouan A, et al: Comparison of Flavivirus universal primer pairs and development of a rapid, highly sensitive heminested reverse transcription-PCR assay for detection of flaviviruses targeted to a conserved region of the NS5 gene sequences. J Clin Microbiol 2001;39:1922-1927.

63 Maher-Sturgess SL, Forrester NL, Wayper PJ, et al: Universal primers that amplify RNA from all three flavivirus subgroups. Virol J 2008;5:16.

64 Johnson N, Wakeley PR, Mansfield KL, et al: Assessment of a novel real-time pan-flavivirus RTpolymerase chain reaction. Vector Borne Zoonotic Dis 2010;10:665-671.

65 Ravanini P, Huhtamo E, Ilaria V, et al: Japanese encephalitis virus RNA detected in Culex pipiens mosquitoes in Italy. Euro Surveill 2012;17:pii = 20221.

66 Platonov AE, Rossi G, Karan LS, Mironov KO Busani L, Rezza G: Does the Japanese encephalitis virus (JEV) represent a threat for human health in Europe? Detection of JEV RNA sequences in birds collected in Italy. Euro Surveill 2012;17:pii $=20241$.

67 Vlachakis D: Theoretical study of the Usutu virus helicase 3D structure, by means of computer-aided homology modelling. Theor Biol Med Model 2009; 6:9.

68 Malet H, Massé N, Selisko B, et al: The flavivirus polymerase as a target for drug discovery. Antiviral Res 2008;80:23-35.

69 Diamond MS: Progress on the development of therapeutics against West Nile virus. Antiviral Res 2009;83:214-227.

70 Beasley DW: Vaccines and immunotherapeutics for the prevention and treatment of infections with West Nile virus. Immunotherapy 2011;3:269-285.

71 Montgomery SP, Brown JA, Kuehnert M, et al; 2003 West Nile Virus Transfusion-Associated Transmission Investigation Team: Transfusion-associated transmission of West Nile virus, United States 2003 through 2005. Transfusion 2006;46:2038-2046.

72 CDC, Centers for Disease Control and Prevention: West Nile virus transmission through blood transfusion - South Dakota, 2006. MMWR Morb Mortal Wkly Rep 2007:56:76-79.

73 Jakubik JJ, Vicik SM, Tannatt MM, Kelley BD: West Nile Virus inactivation by the solvent/detergent steps of the second and third generation manufacturing processes for B-domain deleted recombinant factor VIII. Haemophilia 2004;10:69-74.

74 Hellstern P, Solheim BG: The use of solvent/detergent treatment in pathogen reduction of plasma. Transfus Med Hemother 2011;38:65-70. 
75 Mohr H, Knüver-Hopf J, Gravemann U, RedeckerKlein A, Müller TH: West Nile virus in plasma is highly sensitive to methylene blue-light treatment. Transfusion 2004:44:886-890.

76 Lin L, Hanson CV, Alter HJ, et al: Inactivation of viruses in platelet concentrates by photochemical treatment with amotosalen and long-wavelength ultraviolet light. Transfusion 2005;45:580-590.
77 Gallian P, Vignoli C, Dombey AM, et al: Inactivation of a European strain of West Nile virus in single-donor platelet concentrate using the INTERCEPT blood system. Vox Sang 2006;91:345-347.

78 Irsch J, Lin L: Pathogen inactivation of platelet and plasma blood components for transfusion using the INTERCEPT Blood System ${ }^{\mathrm{TM}}$. Transfus Med Hemother 2011;38:19-31.
79 Marschner S, Goodrich R: Pathogen reduction technology treatment of platelets, plasma and whole blood using riboflavin and UV light. Transfus Med Hemother 2011;38:8-18.

80 Solheim BG: Pathogen reduction of blood components. Transfus Apher Sci 2008;39:75-82.

81 Rock G: A comparison of methods of pathogen inactivation of FFP. Vox Sang 2011;100:169-178. 